\title{
第12回日本老年学会
}

くシンポジゥム II >

\section{高齢化時代における老人のあり方， すこやかに老ゆるために}

\section{司会 那須 宗一 勝沼 英宇}

寿命が延長したことによって, 我々は高齢化時代に突 入したといってよい. しかし，寿命が延びても社会の一 員としてその義務を果すことができないよらな状態, 例 えば「寝たきり」の老人になっていたり，或は社会がま だ老人を受入れる体勢を整えていなかったりする場合に は，老人は社会の谷間におちらこんだと同然で，とても生 きがいなどを感ずることはできないだろう．高㱓化時代 を構成する一員として, 老後を楽しく,すこやかに老ゆ

S. Nasu：中央大学社会学専攻

E. Katsunuma：東京医科大学老人科
るには各人がどういら心構えをもてばよいか，もとより 各人が画く健やかに老ゆる老後像はそれぞれ相異なるむ のがあると思われます。しからば，健やかに老ゆるには ぞのような老後像が最も理想的なものであるか，身体 的, 精神的, 社会科学的, 又心理学的に亘って 4 人の演 者からそれぞれの立場で検討した成果を披露して頂き， これから高龄時代に突入するに当って健やかに老ゆるた めの各人の心構光, 社会とのかかわり合い, 健康の足掛 りを探ってみたい. 


\title{
1. 心理学的立場よりみたる理想的老年像
}

\author{
荒井 保男
}

\section{I. はじめに}

一世紀以上にわたって心理学をして自然科学たらしめ ようとする努力が，多くの学者によって払われてきた. その後の自然科学としての心理学の進歩にはまことに目 ざましいものがある.

元来, 自然科学は実在判断であって, 「ある」「な し」が問題であって本質的に「よし」「あし」の価值を 問わないものである.

しかし，老人の心理を取扱うとき，その背後には， useful Aging, scucessful Aging の考方方一一老年期にお ける「よりよい生」を確立するにはどうしたらよいかと いう考方方一が常につきまとっている.

それは，価値観が大きくかかわってくる世界である が，しかし老年心理学はこの問題を自然科学の名のもと に避けて通ることはできないし，又このような問題に積 極的にとりくんでこと，老年心理学のもつ大きな意義が 存するものであろらと思われる.

本シンポジウムに於ける題名の高齢化社会に於ける老 人のあり方とは，まさしく老年期の「よりよき生」の存 り方であり，つまるところは，理想的な老年の生き方の 探求に外ならない。

そこで私は, 敢て, 自然科学としての心理学の立場に 立ち乍ら, 価値観の入った理想的老年像という題名をか かげた次第である.

\section{II. 理想的人間像と理想的老年像}

理想的老年像を考えるまえに，理想的人間像について 考察してみたい。

理想的人間像は常に社会体制という「わく」や，国境 をもっていることを知らねばならない。

国家の事情によって人間の理想像も異ってくるのであ る.

人間の理想像とは, 結局, 理想像といい乍ら, 社会体 制に即したものであり，相対的なるのである.

Y. Arai：横浜市立大学
資本主義社会には資本主義的理想像が，共産主義社会 には共産主義的理想像が，新興民族主義国家にはその体 制に沿った理想像が存するまたた，理想的人間像は一国 の歷史の中でも, 変化して止まないものである.

敗戦を境とする前後の我が国の人間的理想像の変化を みれば，それは直ちに納得できるところであるう。

しかし，理想的老年像は死を前にして，人間の最終段 階に於ける「生」として，イデオロギーを越えた各国共 通の理想があるように，私には思われる，私はそのよう な理想像を求めて，本論文に於て展開してみたいと思う のである.

\section{III. 理想的老年像の変遷}

理想的人間像は時代により異ると述べたが，老人観も また，時代と共に変遷している.

その時代の老年観に基ついて，その時代の理想とする 老年像が求められた。

ここで我国の老人観に大きな影響を及ぼした吉田兼好 の「従然草」, 貝原益軒の「養生訓「楽訓」を考察し て，両者の理想的老年像をみてみたい。

（イ）徒然草にみる理想的老年像

「生命長ければ恥多し，長くとも四十に足らぬほどに 死なんこそ，めやすかるべけれ」（第7段）というよく 知られた一文は，今まで誤った兼好像を多くの人々の心 に植えつけてきたようである。

最近の安良岡説によれば，この文は37歳の頃の執筆と 考觉られている.

現在，徒然草は長期に及ぶ執筆と考光られ，（第172 段）は48か54歳頃の筆と推定されている. そのなかで, 若者は，「血気らちにあまり，心，物に動きて，情欲お おし．……身を誤つことは，若き時のしわざなり」と記 しているに対し, 老人は, 「精神打とろ充, 淡く扔ろそ かにして，感じ動くところなし」であり，「心おのづか らしづかなれば，無益をわざをなさず，身を助けて愁な く，人の煩いなからんことを思う」と老人の長所をの べ, 老人一般の姿を通じて, 兼好の理想とする老年像を 描いている. 
兼好は年老いることによって，人は初めて安心立命に る似た境地に至り得ることを確知したように思われる。

そして，しばしば己をわきま党ぬ老人を見苦しと酷評 し，年よりらしく行動を慎めとさとし，「老いぬと知ら ば，何んぞ閑にいて身をやすくせざる」といい，老人の 衆に交わりたるも，あいなく見ぐるし，大かたよろづの しわざはやめて，层あるこそ，目安くあらまほしけれ， 世俗の事にたづさわりして，生涯を暮すは，下愚の人な り」と論じている.

これらは何れも，兼好の美の観照観的人生観によるも のではあるが，それはさて扣き，その理想とする老年適 応の生き方は，現代的に云えば，その根底をなするの は, 離脱理論 Disengagement theory であると云うこと ができよう.

離脱理論では，老いることは一般に社会から離脱して ゆくことであり，所属している社会に执いて，他人との 人間関係が弱まってゆくことであるとされている.

離脱理論によれば，老いることによって生じる社会関 係の縮小は必然的なもので，老年期はそれを受容してゆ くプロセスであり, 老人と社会の最善の相互満足が得ら れることが望ましいとしている。

これに異を唱えるのが 活動理論である，活動理論は 体系化された理論というょりは，むしろ，アメリカの中 産階級的価值観を示すものであるとも云われ，要は， 老人は中年の人と同じょうな欲求をもっているものであ って，中年期の活動をできるだけ長く続けるべきで, そのような人こそモラールや，満足感が高いとするもの である.

さて, 兼好の説く理想は, ともあれ離脱論の肯定のよ うに思われる。

（口）益軒の「盖生訓」「楽訓」にみられる理想像 益軒は理気一元論を唱兄た気の哲学者医学者で,「養 生訓」を貫く思想は人間は天地の元気をうけて成立する。 故に, 生の源, 生命の主である気の消耗減退を防ぎ, そ の充足を計らねばならないといらにある.

そこにみられる理想像は，心静かにして，余日を従容 として楽しみ，照すくなくして，晚節を全うするにあ ろ. その説くところは，やはり前述の Disengagement theory に外ならない。

ほぼ同じ頃に書かれたものに「楽訓」がある.

楽訓のなかでは, いかに楽しい晚年を送るかを論じ て理想の老年像を語っている.

益軒の楽しみとは, 自己のなかに生成するエネルギー
の自覚なのであるが, 美しい自然描写から始るこの名文 をまとめれば,

(1) 善を行い

(2) 書を読み

(3) 四時を感じ，月花をめで，草木を愛す.

(4) 天命を知り，死を憂えず

(5) 晚節を全うする

と云うことになる.

養生訓に打いて説く理想像も Disengagement theory に立つものと考㝋てよいが，楽訓に和いて，はじめて， 「老いを楽しむ」といら積極性がみられる，離脱理論の なかにも, 活動理論 (Activity theory) の萠芽がみられ るといってよいであろう.

この兼好と益軒の考方方は，後世に大きな影響を及ぼ した，つい先日の日本が敗れるまで，我々日本人の心を 支配して来たと云っても過言でない。

しかし, 果して Disengagement theory が老後の useful な生き方であろうか。

30年前になるのであるが，たまたま私は大学の内科に 入局し多くの老人と接し, 悠々自適は壮年の夢で, いっ までも働きつづけたいという老人の訴兄の多いのに驚い たことがある。

最近の横浜市民生局が行った老人の生きがい感を調査 した報告でも，70歳以上になっても，働きたいといら欲 求をるって括り，仕事と趣味を共にもちたいと云う老人 が多いのに驚かざるを得ない。

これは戦後の高齢化社会と「いえ」制度の崩壊とも関 係深いものがあるのであろうが, 私はそこで, Disengagement theoryのよさを取り入れつつも，Activity theory の立場に立って，消極的な人間存在の西り方だけに目を むけてきた旧来の老年観とは対照的に, 積極的な性質を もった老人のあるべき理想像を描いてみようと思うので ある.

\section{IV. 遷理想的老年像}

(1) 㑩やかな身体をるつ

老年の理想の第一として先づ身体的な健康をあげなけ ればならないが，私の与えられた課題の範囲外であり， ここではふれない。

(2) はたらきによる生の充実

「生きがい」とは単なる「よろこび」や満足ではな い. 人生全体に意味を与兄て，それに活力を与兄るもの で，人間を人間として存在せしむる根源的なものであ 
る.

その生きがいを求めて, 既にみてきたように多くの老 人は仕事を続けることを望んでいる。

生きがいの中には「他者との交流」「創造的な自己実 現」の要因が存在しているが，仕事程とれらを容易に満 たしてくれるものはないように私には思われる.身体の 健全なるかぎり，仕事をもち，生の充実をはかるべきで あろう. 仕事は労働 (labor) ではない. work である.

ライフワークをもつことが出来たなら, それは何と素 晴しいことであろう。

(3) 美的感受による生の充実

益軒は「あめつちのうち, 四時の行はれ百物のなれる ありさま，目の前にみちみちて，人の見ることを喜ばし め，心を感ぜしむること，大なる楽しみなるかな」とい い，彼の美的能力のかぎりをつくして，日本的自然の美 しさを描写した.

美しいこの自然のなかに楽しみをみつけるのは，益軒 の特許ではない.「万葉」「枕草子」「徒然草」「細 雪」と連綿と続くものである.

一刻一刻と変化してゆく自然や人々を美しく見, 美し く感ずる美的感受による生の充実は, 死が常につきまと っている老年期の人々は，こよなく求めて止まぬもので あろう。

「形見とて なにか残さむ 春は花 山注ととぎす 秋はもみぢ葉」（良寛）

(4) 老いの受容

老年期の心理とは，老いを自覚したら，どのように 「老い」を受容し，どのように自己を変容してゆくか に，かかわっているとも云えるのであるが，我々は老い を自覚してもなかなか受け入れないものである.

Jung は云う, 「常に前進するのが人生の法則であり, それより逃れようとするのは，つまり年をとりたくない と願らのは, 子供時代から抜け出したくないと思うくら い馬鹿げたことだ」と．避けられない身体の衰㝸を受容 できないで，いつまでも抵抗しょうとするのは，不安な 心から生じた神経症の状態とも云ってょいであろう.

受容ということは，あきらめではない。受容というこ と程, 積極的なものはないのである. 受け入れるという ことは，人生のすべてを「諾」と云らことであるとポー ル・トウルニエは云っている.

老いを受容して，更には白楽天が示したよらに，老い を楽しも境地に達し得たら幸である。

(5) 自己実現
Goldste in は精神機能のおかされた場合でさ光どう にかして残された大脳機能を全人格能力に再統合し，自 己実現をはかる根強い傾向が人間に存在していることを 実証し，それが人閒行動の根元的動因と考えている.

同様の有機体的な立場に立って自己実現を唱える心理 学者に Maslow と Rogers がある.

老年期は人生の総決算である. ひたすらゴールに向っ て自己実現を目ざして生きてゆくべきで，それはまた， Jung のいう「個性化の過程」でもあろう.

個性化とは個人に内在する可能性を実現し，より高次 の統合性を志向せしむる努力の過程である.

老年期は今まで社会にあって，押しつけられた型には まった役割から解放されて，自らの独自性を発見すべさ ときでもある.

それは個人の再発見であり, 個人の生活の意義の十分 なる把握である. それは云わば内面化の問題である. 内 面的な豊かさが，老年期の生活に真の意味を与完てくれ るであろら.

(6) Erikson のいわゆる統合の感覚の確立.

Erikson は人生を $8 つ$ 段階に分け，各ライフ・ス テージに達成されるべき課題とその影になる危機とがあ り，その課題を達成することによって，完全な人生を送 ることができるとしている.

Erikson によれば，老年期に課せられた課題は統合で ある (その反対は絶望). Eriksonの理論における統合と は，自分の人生といら事実を受け入れ，死にたいしてそ れ程の恐怖心をもたずに立向らことのできる能力を意味 している.

統合の感覚を確立した人は，自分の過去について，実 存的な観点から眺めることができる. そして，自分の人 生と個性が，個人的な満足と危機の蓄積によって生れて きたものであることを正しく認識する。これまでの諸経 験についてあるものを否定したり，他の事実を過度に強 調したりせずに，全体として受け入れることができると されている.

「統合」の仕事を克服した老人では，高い「生きが い」を所有することが，杉山の研究でも示されている.

しかし，統合を経験するためには，老人は一生涯を 通じての一連の葛藤や失敗や失望を自分のなかにすべて 受け入れなければならないのであって，極めて困難な仕 事であることを肝に銘じて执かなくてはなるまい。

(7) 死の受容と死の超越

Erikson の統合という仕事を克服した人は，死を恐れ 
ないという。

人間だけが死を確認でさる，そして，死を確認したと ころから，本当の人間の生き方がはじまろ.

「生死一如」であり, 更には死を超越出来れば至高で あろら。

釈尊は死ぬ瞬間まで努力精進し, 愛弟子アーナンダに 自分自身の生命の終焉を示して, 諸行無常の真理を説い た.

中江兆民はガンと宣告されるや，少しもたじろがず， ひるまず, ガンと共生して最後の仕事, 「一年有半」に つついて「無神無霊魂」を書きあげ，心豊かに生を全う した.

Frankl は価値を体験価值, 創造価値, 態度価值に分 けている.

人生はいかなる条件のもとにあっても意味をもつもの であり，死，窮境，苦しみに対していかなる態度をと るか, その人間のとる態度によって，人間的な達成へと 向うことができるものであって，「意味と充足」「内面 的な満足」が得られるとし，不屈の勇気をもって，自分 自身の十字架を背負ら人々を高く評価した．寝たきりに なっても, 生の意味を求めて, 不屈の価值ある態度をと ることが望まれよう.

(8) 前向きの生（過去にとらわれない）

益軒は，「かえらざる事をくやまず，過あらば，一た びは，わが身をせめて二度临ず，只天命を安んじてられ ヘず…..」と述べている.

Erikson のいら統合性を確立した人は，今までの諸経 験を, 全体として受け入れることができる筈である.

過去に捉われず，前向きの姿勢で生きることが望まし w.

\section{(9) 社会的活動（他者への愛と奉仕）}

「生きがい」には，他者への関心と愛が存することは 既にのベた。自分一人のために生さることは意味がな く，又，すぐ限界がきてしまう．人間は社会的動物であ り，社会の中で「他者へのために」の活動があって，生 きる喜びが得られる，進んで，社会的活動をすべきであ る.

\section{(10)よき趣味をもつ}

老年期には，余层を上手に使うことが賢明で，よき趣 味をもつことが望しいのは勿論のことである.

(11) 主体的な生

「生きがい」は他者との交流や，創造的な自己実現な

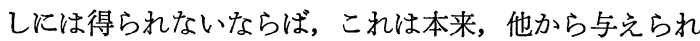

るものではなくて，主体的な生き方から見出されてくる ものであることを忘れてはならない。

いやいや乍ら出て行く老人クラブ活動からは，生きが い感は得られないといら報告のある事を記しておこう.

(12)柔軟な心をもつ（謙虚に他人に耳を傾ける）

老年になると，心的硬さがまし，柔軟性を欠さ，融通 性がなくなり，かたくなになり，時に頑固となる。

自己を客観的にみつめ，自己の欠点をも含めて自己を 受容することができることが，健全な心の持主である.

謙虚に人の言葉に耳をかたむけ，内省することが必要 である，そのような人からは，いまわしい，嫁一姑の関 係などの生ずる筈がないであろう.

(13) 配偶者と共に老いる

配偶者の喪失は老年期精神障害の発生ともかかわりあ いがある.

配偶者の死亡や疾病に伴うて, 神経症や精神障害の発 生をみることが多い。

適応能力が低下し，依存対象がそしい老年期にあって は，配偶者との依存関係は最もかけがえのないものであ る. 互いにいたわりあい，配偶者と共に健かに老いてゆ くことが必要である.

(14) 孤独に耐えることができる

高齢化社会では女性の老後は，「一人暮し」になる可 能性が大きい。平均寿命は男性より 5 歳以上長いうえ に, 結婚年齢は 3 歳程度女の方が若い. 夫が死んだ後, 8 年以上は 1 人で生きてゆかなければならない計算であ る.

「高齢化問題の中心は女性問題」であるとも云われる 所以であるが，男性女性を問わず，不幸にして配偶者を 失うような立場に立ったら，一人で生き，孤独に耐える 強い精神が必要である. 孤独に耐えるどころか, 孤独を 愛すことができたら素晴らしい. Maslow は真の 創造 の源泉は, 純粋な孤独な経験のらちにあることを確めて いる.

(15) 経済的不安に打びやかされない

経済的不安におびやかされていないためには，必ずし も裕福を意味しない。心の問題である。

経剂的に标びやかされない人は，高い「生きがい感」 をもっていることが，心理学的に確められている.

\section{v.むすび}

以上，私の理想とする老年像であるが，価値観は人に より異り，それぞれの理想像があるであろう。しかし， 
共通するものるまた多い筈である．私は万人共通の理想 像を求めてみたのであるが，それはあくまです私の心理 学的立場からの理想像であって，与えられた時間も少 く，補筆し訂正しなければならないところが多々あるで あろう.

大方の批判を得て今後の充実を期したいと思う.
最後に，以上の理想像は老年になってから，求めよう としても容易に求められるものではない，若いときから の努力の上にのみ達成されることを強調するとともに， これらの理想像が達成されるためには, 若い人の心から の協力が必要であり, 温かい環境作りがなされることを 願って，私の責を果したいと思う。 


\section{2.わが国の高齢社会における老人の在り方}

一すこやかに老いるための社会的条件一

\section{大道安次郎}

I. テェマ—すこやかに老いるためには, 肉体的, 精神的，心理的など多くの諸条件の整備とともに社会的 条件の整備の必要なことはいらまでもない。ここではそ の社会的条件について考兄てみたい。

II. 前提条件一その際つぎのことかがらを前提に している.

A. 国際的条件

1. こんごとも世界平和が維持されていること（東西 問題, 南北問題を解決し, 核や化学兵器などの使用によ る大規模の戦争勃発の未然防止に期待をかけて).

2. 世界的規模の大恐慌がないこと.

3. 資源の開発が不断に行われていること.

4. 基本的には現在の 国際交流が 維持されているこ そ.

5. 科学技術（医学も含めて）の 開発・発達等々.

B. 国内的条件

1. 自然的条件の大変化がないこと（極端な気候の変 化，大地震や大噴火がなく，海流の変化もないこと．資 源の不足は海外からの補給によって一応確保されている こと)

2. 社会的条件

1）現在の社会体制（民主主義・自由主義）が基本的 に維持され，国内の平和と秩序が確保されていること.

口) 経済の安定的成長が維持されていること.

八）人口過密, 污染, 貧富の差, 資源の枯渴などが予 想されるが，適切な対策と代替物の開発によってマイナ スを最小限度にとどめること．

$\Rightarrow$ 高齢社会への突入は必然. 同時に核家族化と都市 化子進行.

III. 本論に先立って「すこやかに老いる」ことの意 味について触れておきたい。

Y. Daido : 関西学院大学名誉教授
A.「老いる」ことについて

1. 自然界での老化。たとえば, 自然資源の枯渴, 自 然陶汰, さらに自然環境の悪化, 污染など（赤潮や松哙 虫の発生など).

2. 人間界での 老化. 社会的老化と個人的老化があ る.

イ）社会的老化. たとえば，歴史に見られる民族や国 家の衰亡, さらにゴースト・タウンや市内地域の退廃な ぞ.

口）個人的老化. 生物としての人間の老化は必然的で ある. その老化は肉体面と精神面に見られるが，両面の 老化は必ずしも平行せず，またとの老化のテンポはある 程度制御できるが，不老不死は不可能.

B.「すこやか」(健康)について

「老いる」は必然であるが，「すこやか」は願望であ る. この願望には肉体的健康の維持 - 増進と精神的健康 の維持・増進の二面がある.

1. 肉体的健康とは日常生活を営むことができる条件 を充たしている肉体的状態のことであって，逆にい党ば 病弱な肉体でないといらことである. その意味での健康 体の維持と増進を求めているのが肉体面での願望であ る.

2. 精神的健康とは生きるよろこび（生きがい）と安 定感に支えられた充実した精神状態のことである.この 精神状態の維持と增進を求めているのが, 精神面での願 望である.

生きるよろこびは各人各様であるが，共通点として は, 社会に役立ちたいという願望, 他人に認められたい という願望, 何に生きがいを求めるかを選択する自由へ の願望, 老化が進んだ際に世話をしてもらいたいという 願望, さらに安らかに臨終を迎えたいといら願望などで あろう.

肉体的健康と精神的健康とは車の両輪のような関係に あるが，ときにはアンバランスの関係も見られる．だが 両者の 関係は「健全な精神は 健全な 身体 (肉体) に宿 
る」といわれているように，目的と手段の関係であるこ とも忘れてはならない，それはまた「衣食足りて礼節を 知る」といわれている所以でもあろう.

C.「すこやかに老いる」ことは，「願望」と「必然」 といら次元を異にしたものの交錯したものである.

IV.なお゙つぎのことがらも念頭に入れておく必要が ある.

A. 老化は高龄化とともに進むるのであるが，平均年 跉の延長にともない老年期が長くなる.だから老年期を 段階別に区分してとらえることが必要である．たと党 ば, young old と old young の二分性, 初期, 中期, 後期の三分法など.

B . と同時にこれまでのライフ・サイクルの再検討の 必要.

C. 老人の社会的階級層面での多梯性. 大別すると，

1. 肉体的精神的に不健康なグループ一生活困窮者

2. 肉体的精神的に比較的健康なグループ一生活に 余裕のあるグループ.

D. わが国の特殊性

1. わが国の高齢社会への進行はほかの先進諸国と比 べて異常なスピードである，幸に経済生産性は高いとし ても，狭い国土と貧しい資源のさ中で，環境悪化や污染 を防止しながらの社会的条件づくりは極めて困難なもの がある.

2. そのために社会的条件づくりは短期と長期にわけ ることが必要である. 事後処理と事前対策.

V. さて「すこやかに老いる」ための社会的条件づく りは，以上のことがらを念頭に入れておく必要である が，相手の老人を無視しては画に書いた餅に終る，とい らのは，老人側の役割は表裏の関係にあるからである. だから社会的条件づくりは, 社会的側面からと老人側と から考える必要がある.

A. まず条件づくりの社会的側面

1. 老人の肉体的健康の維持と増進の条件づくりを制 度化すること. その際の問題点.

イ）老化とともに病気勝ちになるので，䂆防と治療と リハビリを包括医療の観点からとくに地域医療を体系化 すること．

従来は保健・衛生・予防部門は政府の役割, 医療部門 は民間の医療機関の役割に二分されていた．それにリ八 ビリの部門を加亲た包括医療の立場から三部門を有機的
に関連づけて，しかも地域に即して体系化すること。

ロ）その際現在の地域医療の格差の是正を見のがして はならない。

八）環境（自然的・社会的）を整備して老人の健康を 守ること.

））老人福祉法の精神を徹底的に生かすこと．その際 の問題点.

i 生活困窮者の老人には老人医療費無料化の完全な 実施は当然であるが，所得制限による医療費一部負担の 導入も当然である. 限られた財源を有効に生かすために は，福祉ばらまきの悪平等はさけるべきである．そして mutual aid と self aid の精神を生かすこと.

ii 病弱のひとり暮しの老人（とくに女性に多い）対 策強化とともに核家族・三代家族などの問題をも再検討 することが必要.

2. 精神的健康の維持と増進の条件づくりを制度化す るための問題点.

1）老人の役割を社会的に再認識し，その能力の活用 をはかることは，老人の社会的に 役立ちたいという基 本的要求（社会的参加を含めて）に答劣るばかりではな く，社会的にもプラスになる，そのためには，

i 定年制延長問題とともに退職後の 再就職問題につ いても制度化することが必要. その際青壮年層との競 合問題, 各企業内部の経営問題をも充分考慮することを 忘れてはならない。

ii 老人の能力を積極的に地域社会に生かす工夫.

口）老人の共通な悩みのひとつは孤独であるから, 彼 らに生きるよろこびを与えるための地域社会での制度づ くりが必要. そのための問題点.

i 老人クラブや老人大学などの在り方の再倹討. こ れまでの行政主導型や一部の老人たちによる運営の在り 方を会員一同が積極的に運営にも自主的に参加するため の再検討が必要.

ii これまでの老人ホームの在り方の再検討. たとえ ば地域住民から遊離した所在地の山上から街中に移すこ となど。

iii 家族形態の在り方の再検討.

iv 生涯教育の場を提供すること. 老人の精神的健康 さを保つためには絶えず新らしい知識や趣味などを身に つける必要がある．そのための機会と場所を提供するこ と.

B. 老人例の役割責任分担

老人の「すこやかに老いる」ための社会的条件をいく 
ら整備しても, 当の相手の老人がそれを主体的に受けと めて活用しなければ無用の長物. 老人側にもそれに答党 るだけの責任と役割がある筈であると点について以 下主なる点について触れてみよう。

1. 老化は必然であるが，できるだけ老化の進行を自 からの努力によっておくらせること．たと党ば，精神的 老化を防ぐために，自ら進んで新らしい知識を身につ けるための生涯教育を実践することや何らかに「生きが い」を求めて生きること.と同時にできるだけ病気にな らないように自ら注意すること.

2. 老人としての誇りを失なわないこと.

1）老人は社会的活動の第一線から退くから, 社会保 障に便らざるをえない。それだけ社会的に負い目を感じ ているが，他面老人でなければ得られない多くの特権が ある. 過去の貴重な経験と英知と公平な立場からの綜合 的判断力，それに充分な自由時間に恵まれているので, それらを社会的に還元することこそが老人の責任であ り，また役割であろう．現にこの老人の特権を充分生か している人たちが各界に見られる. 政界, 経済, 学界, 芸術文化などの各分野での指導者には老人が多い，また 地域でも指導的役割を演じている老人が多い。ある意味 ではわが国は「老人支配の国」または「老人天国」とも いえる.これは老人の特権を生かしているよい例である がこれは例外的といえる.

口）「老害」を自戒すること

老人の指導力には限界がある. 彼らの判断力や統制力 は高齢化とともに硬直化し，新らしい情況への対応力が なくなる，だから自らその限界を悟り，脇役に甘じて欲 しい。たと壳ば，自由時間を活用して社会奉仕に一役を 買らとか，不幸な老人と憂いを分つとか，若い者のよい 相談相手になるとか.

八）老人の権利を逆用しないこと.

社会的弱者としての立場を逆手にとって，むやみにそ の権利を主張することは慎んで欲しい.

）むしろいずれ若い世代も老人になるので，彼らに 身をもってよい老人のモデルを示して欲しいものであ る.

VI. このように「すこやかに老いる」ための条件づ くりは社会的な制度化ばかりではなく，老人例でもその 責任と役割を分担することが必要である. 両々相挨って はじめて「すこやかに老いる」夢が達成されるであろ ら.
しかしその達成のためには，これまでの老人観を根本 的に変兄る必要がある.

これまでの老人観は老人を社会的弱者として社会的厄 介者視していた. 高龄化の歩みとともに肉体的精神的老 化が進むところから, 生産活動には役立たず, しかも病 気勝らである.とれだけ老人の存在は社会的負担とな る. 老齢年金や老人医療費など社会保証費の支出は主と して青壮年層の拠出によって購われている. 老人が多く なればそれだけ社会的負担が多くなる。こうしたところ から老人を社会的厄介者と見るわけである.

この見方は明らかに生産第一主義・効率第一主義に立 つ見方であって，それはまさに青壮年の立場からの見方 である.それは「働かざる者は食うべからず」，「能力 に応じて」の立場からの老人観であり, 老人を社会的弱 者としてとらえている老人観である.

老人にはこのような見方をされる面があることはいな めない，それを素直に認めながらも，老人には青壮年に 見られない優れた面があることも認める必要がある.

そのひとつは，さきにも触れたように老人には過去の 貴重な経験の積み重ねと優れた英知（綜合的判断力）が あることと自由時間に恵まれていることである．これら はいわば老人のみに与えられた特権であって，青壮年達 には無いるのである.

その二は, 老人たちの努力によって, 敗戦後の荒廃し たわが国を現在の繁栄に導く礎が築かれたのである. そ の涙ぐましい過去の努力の跡は忘れてはならない。

その三. さらにあの当時子供だった現在の青壮年たち をあの困難のさ中で現在の老人たちは身を粉にして養育 した苦労もまた忘れてはならない。

その四は，これまでの老人観の底流に流れている生産 第一主義や効率第一主義に対する反省である. 何のため に㗢くのか，それは直接的には生きる糧を生産するため であるが，「人はパンのみに生きる」のであろらか，そ れは人生には「無用の用」, あるいは芸の世界に生きる とか, 宗教の世界に生きるとかいった働き蜂以外の世界 があることに気づくことである．それはまた経済第一主 義, 経済大国への批判でもある.

だが以上は老人側からの青壮年たちの見方に対して求 める反省であるが，老人たちるまた自ら反省すべき点が 多々ある. とくに磒固で過去の伝統のみを固守したり， 「いまどきの若者は」といった態度は厳に反省すべきで あろう.

要は青壮年たちも, 老人たちもこれまでの老人観を改 
めて新らしい老人観を打ちたてることである.いわば青 壮年も，老人も社会的にとって不可欠な要員であること を認め, 相方とも長所を認め合って協力することが何よ りも先決的に必要なことである. そしてそれぞれが人間 として尊重し合うことである.

かくしてはじめて老人も各世代の人びとと手を携えて 「すこやかに老いる」ことが約束されるのである．要は これまでともすれば反目し合っていた各世代間の関係を 見直して，「老若共存と協力の社会」の創造のために新 らしい価値観を確立することである.
ただわが国の場合は他の先進国に見られない異常なス ピードで高齢社会へ突入しているので, 先進諸国から学 ぶべきものは充分摂取しながらも，わが国独自の歩みを しなければならない。そこにはいくたの試行錯誤の繰返 しと苦労の連続を覚悟しなければならないであろう。 さいごに一言.

この報告は時間の制約のため要点のみに触れた。 それ とても私の能力不足のため見逃した点が多々あるである う.この機会にこれらの点について皆さまの御教示を切 に打願いしたい。 


\title{
3. 都市農村老人の疾病構造とその予防対策
}

\author{
一身体面から一
}

\author{
根岸 龍雄
}

\section{1. はじめに}

第 2 次大戦後のわが国に拈ける疾病構造の変化は，き わめて激しく，かつて例をみないものであった．各種の 感染症の減少と慢性扝上び変性性諸疾患の比較的増加, それらから結果する平均寿命の急進は世界史的事象とし て注目を集めている.これらの激変は, 戦後の経済的発 展拈よびこれにともなう社会的ないし文化的展開，とく に都市化，成熟化などとともに，医学敊よびその適用の 進歩によるところが大きいのは当然であろう。しかし， わが国の全体が大きく変化したといっても, 当然, 地域 較差があり，明治以降ずっとそうであったように，いわ ゆる大都市の優先, 過疎地域の追随といら形式で, これ らの変化が進んだのであった. したがって，人口構成の 高龄化とともに，高㱓者は増加したのであるが，都市と 農村に郝ける変化には，かなりの較差がみられることと なったのである。

また，死亡率の 減少は，現在までのところ，年次別 に，注涪直線的減少を示しているのであるが，医療機関 を訪ねる率すなわち受療率は，逆に，ほ涪直線的増加を 示して扣り, 死亡率, 受療率の両者とも, 未だに最終的 な到達点には達していないもののごとくであり, この点 には充分な注意が必要と考兄られる。

また，さらにもら 1 点, 注意すべき点は, 死亡率すな わち死亡危険も, 受療率も, ともに, 生年群別の推移を 示している点である. すなわち，老人と一口にいって も，その生れた年次によって，わが国の激変の受け方， いわば，その生存の履歷が異なって拈り，死亡危険も受 療率も異なっているのである.これは, 近い将来の老人 についても当てはまる事実である.

本研究は, わが国の老人について, 都市と農村という 地域差, 生年群という歴史性をふま兄て, 死亡率=死亡 危険と受療率の時系列的な分析によって考察をすすめ,

T. Negishi : 東京大学医学部成人保健学教室
その予防対策をさぐろうとするものである.

本研究の資料は, 人口動態統計および患者調査など の, いわゆる官庁統計であり, 分析の方法は, コホート 分析および 回帰分析などの一般的方法にとどまってい る.

\section{2. 疾病構造の変遷}

（1）死亡の動向

縦軸に人口 10 万対死亡率を対数目盛上にとり, 横軸に 年龄階級をとって, ある年次の, 総死亡あるいは特定の 疾患の死亡率を示すと, 10 歳近辺の年齢階級から上では 最高齢者までほぼ直線状のグラフを得ることを，かなり 古く Gompertz が示している。これを Gompertz の直線 と仮称すると，わが国ではこの直線が最近になるほど下 方に移動し, 傾斜がわずかずつ大きくなるように変化し た. また，生年群別にみると，後から生れた者注どこの 直線は下方に位置する. しかし, 消化性潰瘍による死亡 などでは, 生年群別に Gompertz 直線をみると, 一定 の年次までは直線的に推移するが，その後は横軸に平行 に，すなわち，一定の死亡率を示して推移することが示 されている。これ医どではないまでも，ある年次までの 直線的推移が，より傾斜のゆるい直線に変化し，しばら く経過した後に，前の直線に平行に，しかしずっと下方 に移動して，再び直線的推移を示す疾患がある。これに は脳血管疾患，胃癌などが含まれている，以上のような 現象は, Susser が「コホート現象」と名づけているが年 齢秩序を保ったまま，注とんど全ての年齢階級に同時に みられるところが特徵的である，後述するように，上記 と逆の動きを示すことも知られているので，われわれ は,これを「死亡率の減少するコホート現象」と呼ん だ.わが国では，多くの疾患でこの現象がみられ，その 結果として総死亡に拈いてもこの現象がみられている. しかし, 逆に「死亡率の増加するコホート現象」む, 肺 癌, 虚血性心疾患などにみられて招り，このような疾患 では, 後から生れてくるものの方が年齢秩序に従って, 

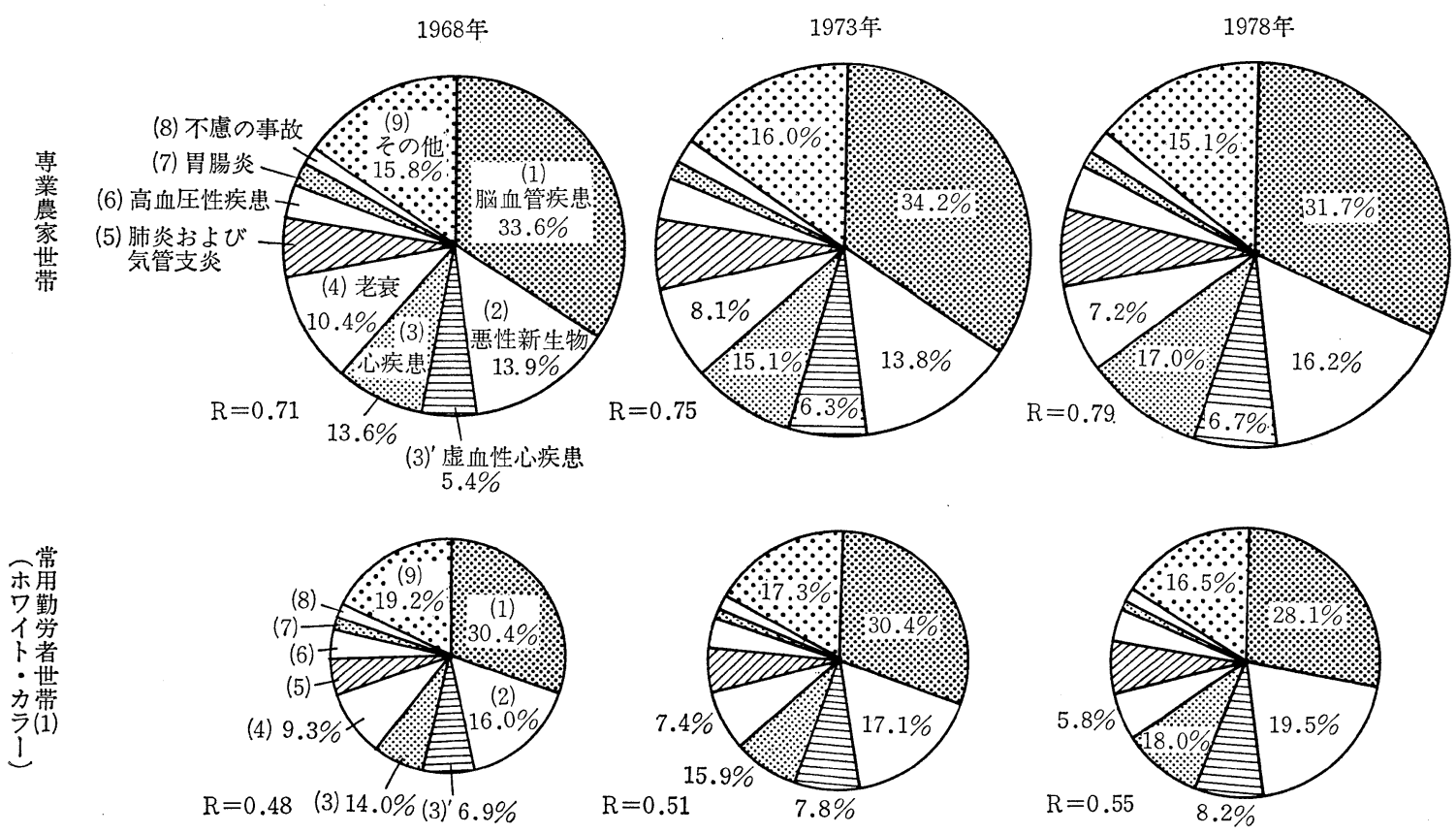

半径 $(R)=65$ 歳以上の死亡数 $/$ 総死亡数

図 1 専業農家とホワイト・カラーの死因別死亡割合の年次推移（65才以上）

順次より高い死亡率を示すこととなるそとて，重要な ことは, これらの 2 つのコホート現象は, やはり, 都市 優先, 農村地域の追随といら形で進行しつつあることで あって，死亡率の減少するコホート現象を示す疾患がき わめて多く, 総死亡るその現象を示しているので, 都市 に比較して農村地域の死亡率の低下がより軽度となる結 果が示されていることとなる. 図1は専業農家世帯とホ ワイトカラー世帯との1968年, 1973年および1978年の, 65歳以上のものの死因別死亡割合と，（65歳以上の死亡 数/総死亡数) である. 農家では65歳以上の 死亡割合が 71\%から79\%に増加しているが，1973年から78年にかけ

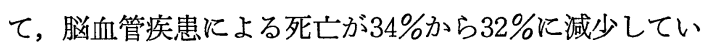
ることがわかる，農家でもホワイトカラーでも老衰によ る死亡の割合は減じているが，悪性新生物扣よび心疾患 による死亡は増加している，また，虚血性心疾患による 死亡の増加はホワイトカラーの方が大きいことが示され ている.

ここで母集団の人口を示して括くと，昭和48 (1973) 年で人口 5 万人以上の都市の人口は総人口（約 1 億 870 万）の $66 \%$ ，その他の地域の人口は34\%であり，2/3が 都市に居住しているとい党る. しかし，この比はその後
より大きくなり，21世紀初頭には，わが国人口の70\%以 上，約 1 億人が都市に居住するものと考えられている.

（2）死亡率と受療率との関係

前述したように, 死亡率は，ほぼ直線的減少を年次別 に示しているのに対して, 受療率は直線的増加を示して いる. 両者の関係を年龄階級別に，1955年から79年まで の 推移で示したものが図2である. 四に示すように, $5 \sim 14$ 歳では, 死亡率の減少とともに受療率が増加する が，近年では受療率も減少に向っている．45～54歳の年 齢階級までは，図にみられるように，この傾向が全て示 されている. そして，55〜64歳では受療率は変化せず, 死亡率の及減少している. 図に示すように，65 74歳の ものも，ほぼこの傾向を示しはじめているまた，75歳 以上では，受療率の停滞には至っていないが，図に示す ように，近年になって，先端が左に傾きつつある，以上 を要約すると，受療率が高くなるほど死亡率は低下を示 すが，この傾向は若年龄層のものほど明確で，その死亡 率の減少も大きい. 65歳以上の高年龄層ではこの傾向を ゆっくり追随する形を示しつつあるところであるという ことができう．このことは，老人の疾病予防対策に関 して重要な示唆を与えるものであるといらことができよ 


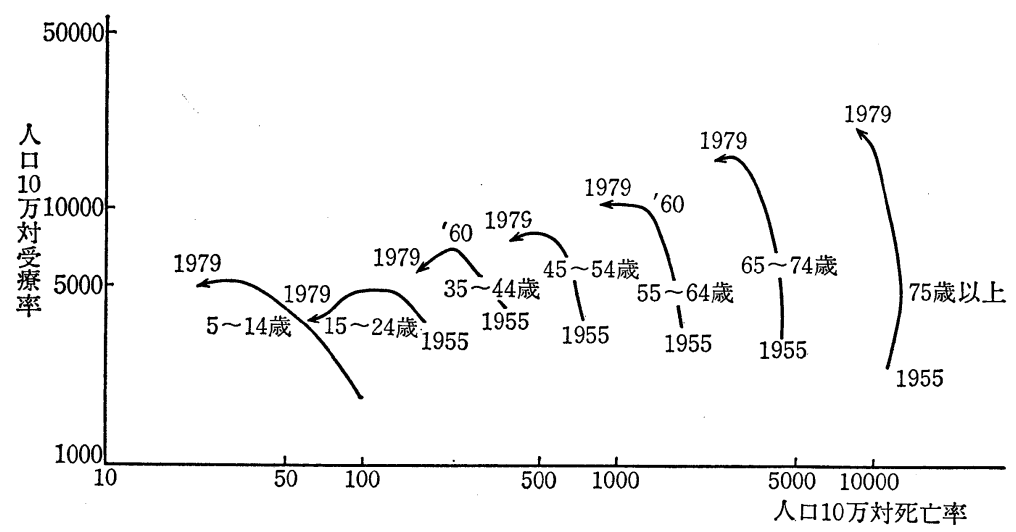

図 2 年令階級別受療率と死亡率の推移

う.すなわち，1955年以後，観察された全年齢階級にお いて，受療率は上昇するのであるが，より若干年齢層ほ ぞ，より速く死亡率の低下がともない，やがて受療率も 低下寸るもののごとくであって，65歳以上の年龄階級に 扣いては，ようやく受療率の停滞に近づいた時点であ り，今後は受療率が死亡率とともに低下することが充分 に期待できるもののごとくであると考察できるものであ る.

次に疾患別に死亡率と受療率の動向を検討すると以下 のごとく 3 型に分けて考察することができる．第 1 の型 は総死亡率と総受療率の動向に一致するものであり，死 亡率の活ぼ直線的減少と受療率のほぼ直線的增加を示す ものである.ここには, 脳血管疾患, 多くの感染症など が含まれる．第 2 の型は死亡率の推移は注ぼ一定の值を とり, 受療率のみ直線的増加を示すもので, 高血圧性疾 患 (女)，虚血性心疾患（女）などである，第 3 の型は 死亡率も受療率もほぼ直線的に増加を示すもので, 悪性 新生物代代表されるものであり, 糖尿病, 虚血性心疾患 （男）などが含まれる，乙かし，糖尿病特よび虚血性心 疾患の死亡率の絶対値はあまり大きくない．

（3）受療率の動向

わが国では，1972年ごろまでは，全年齢階級において 人口10万対受療率は, あまり大きな較差は認められなか った. しかし，1973年以後は55〜64歳以上，特に65〜74 歳㘧よび75歳以上の年齢階級において，受療率の急増が みられた．これは地方および国の政策によるところる， もちろん考兄られよう．しかし，総受療率はこの前後で 比較的なめらかに経過して和り，大きな不連続性が認め られるわけではない。そして，たと兊ば，1955年におい
ては, 最も高い受療率を示す生年群は1921〜30年に生れ たものであったが，1965年には，1901〜10年の生年群が 最高の受療率を示し，以下，年齢秩序にしたがって，よ り高龄のものほど，より受療率が高いといら形を保って 推移したのである. として，1970年と1975年を比較する と，先にも述べたように，1931〜 40年と1941〜 50年の 2 つの生年群では受療率の 低下が示され，生年群の間の 受療率の較差はより大きいものとなってきているのであ る. そして，受療率を疾患別に，生年群別に検討する と, 結核症では, 後から生れたものの方がより受療率が 低いのであるが，他の汪とんど全ての疾患では後から生 れたものの方が，ょり高い受療率を示して 経過してい るのである。いわば「受療率の増加するコホート現象」 が，ほとんぞ全ての疾患についてみられている。しか し，上述したように，年齢階級別には，すでに若年齢層 で，程度の差はあるが，受療率の低下が示されているの で, 近い将来には「受療率の増加するコホート現象」が 終ることが考察される。

次に受療率の人口規模別，高齢者の年齢階級別，疾患 別に検討すると以下のごとくである.すなわち，まず総 数でみると， 10 大都市， 20 万以上の都市， 5 万以上の 市，その他といら人口規模別に，また，65〜69歳，70〜 74歳, $75 \sim 79$ 歳 掞よび80歳以上という年齢階級別にみ て，10大都市，20万以上都市括よび 5 万以上の市に拈い ては注ぼ全年齢階級に和いて大きな人口規模別の較差は なく，その他（人口 5 万以下の市町村）の及が若干受療 率が低い．年軨階級別には，70７4歳および75～79歳の 年齢階級に打いて，若干受療率が高く，80歳以上で受療 率が低い。これと類似の傾向は，疾患別には，消化性潰 

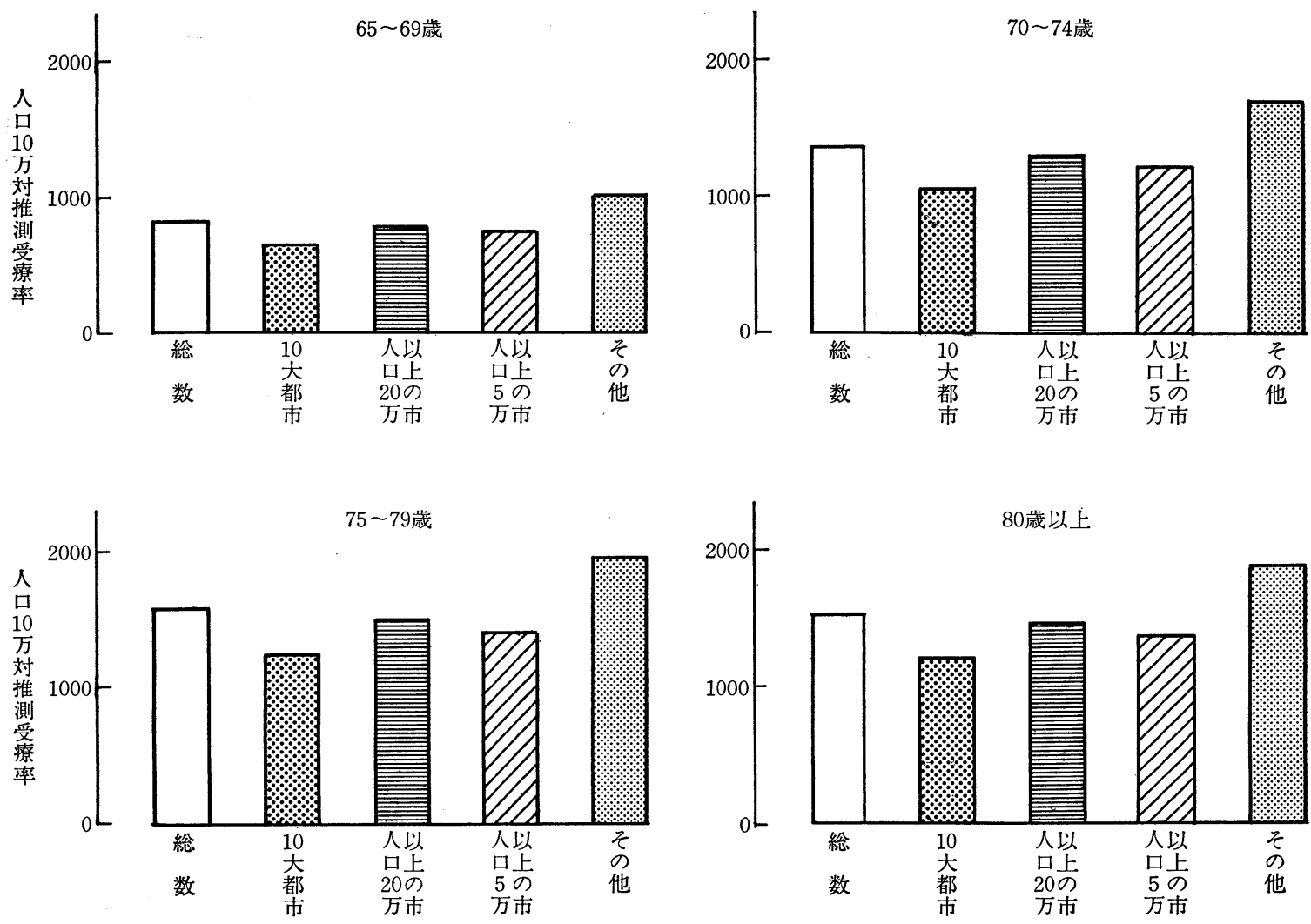

図 3 1973年の人口規模別傷病分類別受療率に基づく1973年の年令階級別受療率の推測脳血管疾患（再掲）

瘍，虚血性心疾患などがある１0大都市が高く，その他 まで順次，受療率が低くなるものに歯の疾患，消化器系 の疾患拉よび呼吸器系の疾患がある。この場合も70〜74 歳扣よび75〜79歳のものの受療率が他の年齢階級よりも 高い．20万以上の都市が10大都市よりも， 5 万以上の市 およびその他よりも高いものに，悪性新生物，不慮の事 故, 糖尿病和よび筋骨格系の疾患がある. また，その他 が最も高い受療率を示すものに, 循環器系疾患, 脳血管 疾患招上び高血圧性疾患があり，特に脳血管疾患に执い ては，図 3 に示すょうに，ほぼ，人口規模の大きい順 に，より低い受療率が示されている。この場合，より高 年齢の年齢階級のものの方がより受療率が高くなってい るのは注目されねばならない５万以上の市で最も高 く，人口規模が大きくなるにつれて，受療率がより低く なり，10大都市とその他が注涪等しい值をとるものに精 神障害がある。この場合には，年龄階級による較差はほ とんどみられず，どの年齢階級でも，注ぼ等しい受療率 が示されている.

\section{4) 平均余命の動向}

平均余命は疾病構造の集合像の一面を示するのと考兄 ることができるが，先に述べた死亡率の動向から考兄ら れるように, 生年群別の較差があり, 後から生れたもの ほぞ平均余命が長い。たと党ば，60～64歳においては， 10 年後に生れたものは，注涪 1 年弱平均余命が長くなっ ている. しかし，より高年龄では，その伸びはより短い ものとなる.この伸びは1971年まではかなり速かった が，その後はやや遅くなっている。

\section{3. 予防対策}

(1) 経済的側面

平均余命の動向については，上述した通りであるが， 巨視的にはその動向と医療費との関係をみたものが図 4 である．ここでは，国民総生産に占める国民医療費の\% と平均余命（0 歳，女）との関係を検討している. 1954 年から1971年までは，図に示すように，

(平均余命) $=47.9+8 \times($ 上記 $\%)$ 


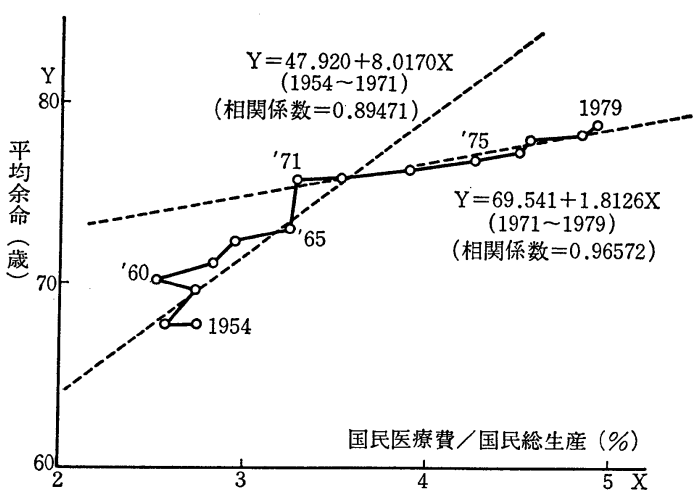

図 4 国民医療費国民総生産と平均余命（女）

の関係を示していたが，1971年から1979年にかけては， (平均余命) $=69.5+1.8 \times$ (上記 $\%$ )

となって，1971年までの対国民総生産一国民医療費百分 率の係数よりも，より低い係数となっている. しかし， ほぼ, 線型（相関係数=0.97）とみなせるので, 近い将 来も, ほぼこのレベルで推移すると考えられる. しか し，わが国もすでに低成長時代に入っており，国民医療 費に対する批判の声も聞えている，省エネルギー時代に ふさわしく, 経済的効率がより高くなることが求められ るかも知れないが，すでに，図 2 に示したように，若年 の年龄階級に和いては, 死亡率も受療率も減少してきて おり，この傾向は高年齢階級にもみられはじめている. すなわち, 今しばらくの間の時間的遅れのうちに, 高年 齢層においても死亡率と受療率の両者が低下寸る期待は 充分にもてるものと考兄らるのである. あちろん，医 療の側においても, 平均余命をより延長する方向で節減
できるものはすべきであろう．いずれにせよ，高年齢層 の受療率の動向を厳重に注目していなければならない.

2) 生態学的側面

先に述べたように, わが国の大戦後の発展の中で, 多 くの疾患死亡について，「死亡率の減少するコホート現 象」が認められた.この現象のおこった理由あるいは原 因などは，現在のところ全く不明である．広く生態学的 ネットワークがこの結果を示したと思われるが，もちろ ん，医療の発展掞よび医療の適用の展開が大きく影響を 与えた結果と思われる.ここで，年龄秩序を保ったま ま，ほぼ全ての年噛階級にみられたことは，より注目さ れねばならないであろう。もちろん，今日，われわれ は, その結果のみを知るのみであるが, 大都市所在の都 道府県において，コホート現象がより明確に示されたこ とは示唆の 1 つなろう。

3）管理システムの側面

わが国では結核症を対象としてはじめられた疾病管理 の経験があり,さらには近年循環器疾患, 糖尿病などの 多数の疾病管理の研究がすすめられている. 高年齢者を 対象とする管理システムの研究結果も多数報告されてい る.しかし, 地域社会において, 現実の要求に応ずるシ ステムは, 未だ, 比較的小規模のものといわざるを得な い. 高年齢層に叔いて受療率が低下する時点が比較的に 近いと想定できるとすれば，その時までには，全国的レ ベルでの管理システムの試案が用意されることが 望ま しいのではあるまいか. その管理システムによって, 再 び，「死亡率の減少するコホート現象」が期待できるか も知れないのである. 


\section{4. 都市・農村における老人の疾病構造}

一精神疾患について一

\section{加藤 正明}

\section{老人の精神疾患の現状}

老人の精神疾患の現状と動向について考察する場合, 通常これを「老化にもとづく精神疾患」と「老化に関係 ない，老年期における精神疾患」に分けることになって いる. 前者は, 脳変性に上る老年痴呆と脳血管性痴呆で あり，両者を合せて老化性痴呆と呼ぶものあある.

国際疾病分類 ICD 第 9 回修正では,

1. 老年痴呆, 単一型

2. 初老期痴呆

3. 老年痴呆, 抑らつまたは妄想型

4. 老年痴呆, 急性錯乱状態を伴うもの

5. 動脈硬化性痴呆

6. その他

7. 分類不能

となって拈り,アメリカ精神医学会の DSM IIIでは,

1. 一次性変性痴呆 Primary Degenerative Dementia （老年期発病）
a) 譫妄型
b) 妄想型
c) 抑らつ型
d) 単一型

2. 一次性変性痴呆 (初老期発病)
a) 譫妄型
b) 妄想型
c) 抑らつ型
d) 単一型

3. 多発栓寒性痴呆 Multi-infarct Dementia
a) 譫妄型
b) 妄想型
c) 抑らつ型
d) 単一型

となっている. しかし脳変性痴呆と脳血管性痴呆が重複

M. Kato：国立精神衛生研究所
することがあり，ソ連の Sternberg などは実際にはその 方が多いといっている.

老化に直接起因しない老年期に和ける精神障害としてて は, 老年期にみられる精神分裂病, 躁らつ病, 精神薄 弱, 神経症, 心身症, アルコール依存, 人格障害などで ある.すでに何らかの精神疾患に罹患したものが加齢し た場合もあれば，老年期になって発病したものもある。 それらは加齢現象といら色彩を示しているが，本質的に は青壮年期に生ずる精神疾患と变らないものとみなされ る. 従って抑らつ型の老年痴呆と老年期にみられるらつ 病, 妄想型の脳血管性痴呆と老年期の精神分裂病とは, 病状や経過乞の他から区別される.

これらを含めた老人の精神疾患が，一般人口内にどの 程度に存在するかという有病率について多くの報告があ るが，しばしば引用されるのは，イギリスの D. W. K. Kay によるアメリカ，イギリス，デンマーク，ノルウ ェイなどの統計である ${ }^{122)}$ (表 1). この表によると, 老 年痴呆々 脳血管性痴呆を合せて, 老年人口の $2.5 \%$ から $5 \%$ であり, 精神分裂病, 躁うつ病, その他の精神病を これに加えると $3.9 \%$ から $8 \%$ になり，さらに軽度の精 神老化, 神経症, 性格障害をいれると, 実に18.5\%か ら $30.9 \%$ に達する. なお，表中 J.Bremer と E.EssenM $\phi$ ller は60歳以上の 人口についてであるが，他は65歳 以上の人口となっている. 日本で信頼すべき統計とし て, 長谷川和夫, 柄沢昭秀らが, 東京都 の65歳以上の 人口の無作為抽出対象に 対して行った調查が， $4.5 \%$ と いら比率を示している4). この比率は加龄とともに上昇 し, 老化性痴呆の 有病群は, 65 69歳 $2.0 \%, 70 \sim 74$ 歳 $2.6 \%, 75 \sim 79$ 歳 $6.1 \%, 80 \sim 84$ 歳 $13.7 \%, 85$ 歳以上 26.8 \%となっている. とくに80歳以上になると男性よりも女 性において高率となる。

次にこれらの老年期の精神疾患の推移を知るために, 精神病院に入院した老年期の精神疾患患者の推移を検討 してみた。昭和43年から同54年に至るわが国の精神病院 入院患者の年齢別, 人口 10 万人比の推移は表 3 のごとく 
表 1 老年精神障害の有病率 $(\%)$

\begin{tabular}{|c|c|c|c|c|c|c|c|}
\hline 老年精神障害 & $\begin{array}{c}\text { Sheldon } \\
(1948) \\
\mathrm{N}=369 \\
65+\end{array}$ & $\begin{array}{c}\text { Bremer } \\
(1951) \\
\mathrm{N}=119 \\
60+\end{array}$ & $\begin{array}{c}\text { Essen- } \\
M \varnothing \text { ller } \\
(1956) \\
N=443 \\
60+\end{array}$ & $\begin{array}{l}\text { Gruenberg } \\
(1961) \\
\mathrm{N}=1592 \\
65+\end{array}$ & $\begin{array}{c}\text { Primose } \\
(1962) \\
\mathrm{N}=222 \\
65+\end{array}$ & $\begin{array}{c}\text { Nielsen } \\
(1963) \\
\mathrm{N}=978 \\
65+\end{array}$ & $\begin{array}{c}\text { Kay } \\
(1964) \\
\mathrm{N}=2173 \\
65+\end{array}$ \\
\hline $\begin{array}{l}\text { 老年性执よび脳動脈硬化 } \\
\text { 性精神病 } \\
\text { その他の器質症候群 } \\
\text { 主要な機能性精神病 }\end{array}$ & $\begin{array}{l}3.9 \\
- \\
-\end{array}$ & $\begin{array}{l}2.5 \\
- \\
4.2^{*}\end{array}$ & $\begin{array}{l}5.0 \\
- \\
1.1 \\
\end{array}$ & - & $\begin{array}{l}3.6 \\
0.9 \\
1.4\end{array} 4.5$ & $\begin{array}{l}3.1 \\
- \\
3.7^{*}\end{array}$ & $\begin{array}{c}4.6 \\
1.0 \\
2.4 \\
\end{array}$ \\
\hline 精神病（合計） & 3.9 & 6.7 & 6.1 & 6.8 & 5.9 & 6.8 & 8.0 \\
\hline $\begin{array}{l}\text { 軽度の精神老化 } \\
\text { 神経症および近縁疾患 } \\
\text { (中等度または重度のあの) } \\
\text { 性格障害 }\end{array}$ & $\left.\begin{array}{c}11.7 \\
9.4 \\
3.2\end{array}\right\} 12.6$ & $\left.\begin{array}{c}- \\
5.0 \\
12.6\end{array}\right\} 17.6$ & $\left.\begin{array}{c}10.8 \\
1.4 \\
10.6\end{array}\right\} 12.0$ & - & $\left.\begin{array}{r}10.4 \\
2.2\end{array}\right\} 12.6$ & $\left.\begin{array}{c}15.4 \\
4.0 \\
4.7\end{array}\right\} 8.7$ & $\left.\begin{array}{c}5.7 \\
3.9 \\
3.6\end{array}\right\} 12.5$ \\
\hline
\end{tabular}

* : いわゆる constitutional および心因精神障害を含む

表 2 人口 10 万対精神障害比率

(M. Kramer “Applications of Mental Health Statistics. WHO, 1969より)

\begin{tabular}{|c|c|c|c|c|c|c|c|c|c|}
\hline & 全数 & 補正 & $<15$ & $15 \sim 24$ & $25 \sim 34$ & $35 \sim 44$ & $45 \sim 54$ & $55 \sim 64$ & $\geqq 65$ \\
\hline \multirow{2}{*}{ 了メ省1964) } & 262.8 & 276.2 & 12.0 & 126.7 & 250.2 & 306.5 & 455.4 & 666.1 & 738.9 \\
\hline & 255.5 & 246.8 & 5.1 & 64.9 & 156.6 & 273.5 & 424.2 & 608.3 & 857.4 \\
\hline \multirow{2}{*}{$\begin{array}{c}\text { オーストラリ } \\
\text { ア (ビクトリ } \\
ア)(1961)\end{array}$} & 360.8 & 374.8 & 110.7 & 245.3 & 306.3 & 434.8 & 513.9 & 731.4 & 924.0 \\
\hline & 377.0 & 361.5 & 94.6 & 212.4 & 247.9 & 376.5 & 504.8 & 737.3 & $1,094.6$ \\
\hline \multirow{2}{*}{ フ ランン } & 220.3 & 220.9 & 3.1 & 145.3 & 303.9 & 371.8 & 395.4 & 342.9 & 272.9 \\
\hline & 218.7 & 190.7 & 1.4 & 97.8 & 184.3 & 244.3 & 339.1 & 391.6 & 474.4 \\
\hline \multirow{2}{*}{$\begin{array}{c}\text { デンマーク } \\
(1962)\end{array}$} & 216.9 & 198.4 & 2.6 & 58.0 & 136.5 & 222.6 & 321.7 & 463.9 & 712.9 \\
\hline & 260.9 & 219.2 & 0.4 & 68.0 & 143.5 & 210.1 & 334.3 & 499.6 & 909.4 \\
\hline \multirow{2}{*}{$\begin{array}{c}\text { ポーラント } \\
(1959)\end{array}$} & 109.6 & 119.1 & 16.9 & 95.4 & 185.7 & 213.4 & 188.7 & 138.4 & 85.8 \\
\hline & 90.5 & 96.2 & 6.6 & 47.8 & 131.3 & 169.2 & 191.8 & 148.7 & 90.8 \\
\hline 本*男 & 286.0 & & & 210.0 & 481.0 & 534.0 & 415.0 & 311.0 & 231.0 \\
\hline (1968) 女 & 228.0 & & & 164.0 & 320.0 & 380.0 & 318.0 & 310.0 & 258.0 \\
\hline
\end{tabular}

\begin{tabular}{cc|c|c|c|c|c|c|c|c|c|c|c}
\hline & 全数 & 補正 & $<10$ & $10 \sim 19$ & $20 \sim 24$ & $25 \sim 34$ & $35 \sim 44$ & $45 \sim 54$ & $55 \sim 64$ & $65 \sim 74$ & $\geqq 75$ \\
\hline $\begin{array}{c}\text { イギリス } \\
(1960)\end{array}$ & 女 & 262 & 234 & 1 & 16 & 61 & 188 & 315 & 384 & 576 & 673 & 788 \\
\hline
\end{tabular}

*: 加藤が整理追加

である.この期間に全年齢人口比は 1.12 倍に増えている が，65歳以上の人口比では1.7倍の増加である. しかも 34歳以下の年龄層に打ける入院患者の人口比は歴年減少 し，そのピークは 45〜 54歳へと移行している. 65歳以上 の入院患者人口比も上昇して拈り，今後10１5年の間に 65歳以上の年齢層の人口比をピークとする欧米型の精神 病院の年齢構成になることを示唆している.

この年齢層別人口比を欧米のそれと比較すると表 2 の ごとくである．25〜44歳の 年齢層の人口比は日本が高
く，65歳以上では日本がまだ低いことを示している.ア メリカではその後, 老化性痴呆患者を大量に病院からナ ーシングホームに移したが，これらをいれればその差は な㓡明らかであると思われる ${ }^{122)}$.

\section{都市・農村の比較}

以上の老年期精神疾患が都市と農村でどのような差を 示しているかといら比較検討が求められている. もとも と都市, 農村自体の差が次第に縮められていると考えら 
表 3 精神障害 性・年令階級別 入院患者率（人口10万対）

\begin{tabular}{|c|c|c|c|c|c|c|c|c|c|c|c|c|c|c|c|c|c|c|c|c|c|c|c|c|}
\hline \multirow[b]{2}{*}{ 年 } & \multicolumn{3}{|c|}{ 総 数 } & \multicolumn{3}{|c|}{ 1414才以下 } & \multicolumn{3}{|c|}{ 15ー24オ } & \multicolumn{3}{|c|}{$25 \sim 34 オ$} & \multicolumn{3}{|c|}{$35 \sim 44 才$} & \multicolumn{3}{|c|}{$45 \sim 54 オ$} & \multicolumn{3}{|c|}{ 55〜64オ } & \multicolumn{3}{|c|}{65 才以上 } \\
\hline & 総数 & 男 & 女 & 総数 & 男 & 女 & 総数 & 男 & 女 & 総数 & 男 & 女 & 総数 & 男 & 女 & 総数 & 男 & 女 & 総数 & 男 & 女 & 総数 & 男 & 女 \\
\hline 43 & 213 & 251 & 178 & 8 & 10 & 5 & 163 & 187 & 139 & 356 & 446 & 268 & 389 & 478 & 301 & 301 & 339 & 270 & 243 & 268 & 220 & 187 & 188 & 186 \\
\hline 44 & 212 & 250 & 176 & 9 & 10 & 8 & 157 & 179 & 134 & 344 & 421 & 268 & 371 & 466 & 277 & 327 & 381 & 283 & 254 & 285 & 226 & 185 & 193 & 179 \\
\hline 45 & 200 & 239 & 163 & 4 & 5 & 4 & 142 & 171 & 113 & 324 & 401 & 249 & 368 & 469 & 267 & 302 & 340 & 271 & 244 & 267 & 223 & 169 & 188 & 155 \\
\hline 46 & 225 & 266 & 185 & 7 & 8 & 6 & 166 & 200 & 133 & 352 & 438 & 267 & 405 & 508 & 302 & 352 & 405 & 308 & 271 & 289 & 255 & 194 & 204 & 185 \\
\hline 47 & 224 & 265 & 186 & 5 & 5 & 4 & 161 & 187 & 134 & 340 & 426 & 256 & 406 & 510 & 302 & 348 & 397 & 306 & 283 & 304 & 266 & 215 & 322 & 201 \\
\hline 48 & 222 & 261 & 185 & 9 & 10 & 7 & 154 & 179 & 128 & 321 & 397 & 245 & 407 & 512 & 302 & 351 & 412 & 298 & 278 & 291 & 268 & 217 & 214 & 219 \\
\hline 49 & 230 & 272 & 190 & 4 & 4 & 4 & 143 & 174 & 112 & 347 & 431 & 265 & 421 & 527 & 315 & 368 & 429 & 313 & 301 & 323 & 283 & 212 & 219 & 206 \\
\hline 50 & 222 & 264 & 181 & 3 & 3 & 3 & 133 & 162 & 104 & 310 & 388 & 230 & 413 & 519 & 306 & 362 & 429 & 301 & 288 & 311 & 270 & 226 & 229 & 223 \\
\hline 51 & 226 & 264 & 190 & 5 & 6 & 4 & 125 & 146 & 103 & 302 & 369 & 235 & 407 & 505 & 309 & 386 & 460 & 317 & 321 & 351 & 298 & 234 & 224 & 241 \\
\hline 52 & 237 & 277 & 198 & 4 & 4 & 4 & 115 & 136 & 93 & 315 & 379 & 250 & 438 & 546 & 330 & 415 & 498 & 334 & 321 & 341 & 306 & 243 & 245 & 242 \\
\hline 53 & 229 & 264 & 196 & 5 & 5 & 5 & 106 & 120 & 91 & 300 & 363 & 237 & 410 & 500 & 320 & 397 & 471 & 325 & 327 & 349 & 310 & 252 & 250 & 254 \\
\hline 54 & 240 & 281 & 200 & 3 & 3 & 3 & 92 & 105 & 79 & 295 & 368 & 222 & 416 & 515 & 318 & 416 & 517 & 317 & 363 & 403 & 331 & 318 & 300 & 323 \\
\hline
\end{tabular}

表 4 市部郡部別年令別精神障害者病率（人口千対）

\begin{tabular}{|c|c|c|c|c|c|}
\hline & & 総数 & $0 \sim 19 才$ & 20 20才 & 60 オ \\
\hline \multirow{3}{*}{ 総 } & 六 大都 市 & 8.3 & 5.2 & 8.7 & 17.9 \\
\hline & その他の都市 & 11.7 & 8.1 & 12.3 & 23.6 \\
\hline & 郡 & 16.9 & 14.0 & 19.5 & 16.4 \\
\hline \multirow{3}{*}{$\begin{array}{l}\text { 精 } \\
\text { 神 } \\
\end{array}$} & 六 大都 市 & 4.8 & 1.3 & 5.4 & 14.3 \\
\hline & その他の都市 & 5.2 & 1.9 & 5.5 & 17.5 \\
\hline & 郡 & 7.6 & 4.5 & 9.4 & 10.5 \\
\hline \multirow{3}{*}{$\begin{array}{l}\text { 精 } \\
\text { 蕅 } \\
\text { 薄 }\end{array}$} & 六大都市 & 1.5 & 2.6 & 1.2 & - \\
\hline & その他の都市 & 3.7 & 5.6 & 2.7 & 1.5 \\
\hline & 郡 & 6.2 & 8.4 & 5.6 & 1.2 \\
\hline \multirow{3}{*}{$\begin{array}{l}\text { そ } \\
\text { の } \\
\text { 他 }\end{array}$} & 六大都 市 & 2.0 & 1.3 & 2.1 & 3.6 \\
\hline & その他の都市 & 2.1 & 0.6 & 4.1 & 4.6 \\
\hline & 郡部 & 3.1 & 1.0 & 4.5 & 4.7 \\
\hline
\end{tabular}

表 5 世帯業態別年令別有病率

\begin{tabular}{|c|c|c|c|c|}
\hline 世帯 業態 & 総数 & $\begin{array}{c}0 \sim \\
19 才\end{array}$ & $\begin{array}{l}20 \sim \\
59 才\end{array}$ & $60 才 \sim$ \\
\hline 総 数 & 12.9 & 9.8 & 13.9 & 19.9 \\
\hline $\begin{array}{l}\text { 耕地面䅣 } 0.3 \text { ○クター } \\
\text { ル以上の世帯 }\end{array}$ & 15.3 & 12.1 & 17.8 & 16.7 \\
\hline 事業経営者世帯 & 10.2 & 8.2 & 10.2 & 18.0 \\
\hline 常用勤労者世帯 & 9.6 & 7.4 & 9.4 & 24.5 \\
\hline 日雇労働者世帯 & 30.4 & 20.5 & 39.3 & 26.8 \\
\hline その他の就業者の世帯 & 16.3 & 13.4 & 59.0 & 14.1 \\
\hline 就業していない世帯 & 36.3 & 17.5 & 18.3 & 21.7 \\
\hline
\end{tabular}

れるが, 全国の65歳以上の人口の $64 \% ， 3$ 分の 2 近くが 都市に生活して赫り，都市では60歳以上のもののみの世 帯数がその70\%を占めている.

都市と農村に抢ける老人の精神疾患の比較は，充分な 新しい資料に乏しいが，厚生省が昭和38年に行った全国 精神障害実態調查についてみると次のごとくである ${ }^{32}$.
まず表 4 亿示されるように，60歳以上の精神疾患の有病 率は六大都市よりも「その他の都市」において高いこと を示している。また世帯業態別でみると表 5 のごとく で，全体では日雇労働者に高いが，60歳以上では常用勤 労者に高くなっている. 全国の公衆衛生基礎調査地区を 層別無作為に抽出して調査を行った結果であり，事例発 見の難易も関連するが，六大都市よりも中小都市に多い ということは, 都市, 農村の差というょりも, 都市化過 程と関連するものと思われる. 即ち, 急激な人口増加や 過密化が進行し, これに対する社会資源の供給が遅れて いることである.そしてそれは有病率自体の堌加といら よりも事例として問題になる比率の増加を示するのと考 兄られる. 都市化とともに核家族化が急速に進行し，老 人のみの世帯が増加していくならば，かつて拡大家族の なかで温存されてきた老人の精神疾患があらわになり， 老人の精神疾患者を家族内に抱えていくだけの耐性が急 激に低下している. かつては精神疾患とくに老化性痴呆 があっても家庭内で抱兄られていた老人が，事例として 顕現し, 精神病院への入院患者となる年齢別人口比が増 えているのである.

\section{まとめ}

恐らく戦前の日本にも欧米と変らぬ老人の精神疾患之 くに老化性痴呆が，人口比としては同様に存在しなが ら，入院事例とはならなかったのであろう。このことは 都市化による事例の増加についても同様であり, 発展途 上国で老化性痴呆が発展国と同様の人口比に存在しなが ら，「事例」として入院するものが汪とんどないことと も共通するものであろう.

筆者はこの差を以前から「疾病性 illness」の次元と 
「事例性 caseness」の次元として区別しておう，高度の 老化性痴呆の人口比は, 都市, 農村を問わず, 発達国々 途上国とを問わず，注湆同比率に存在しながら，都市化 が急激に進んでいる中小都市や, 急激に発展しつつある 国では，老化性痴呆という疾病は同比率であっても，事 例となる比率が増加し, 拡大家族のなかで老化性痴呆を もつ老人を抱兄ていられるところでは，同じ疾病率をむ っていても事例になることが少ないと考兄れるのであ る.

従って今後ますます「事例」になるものが増えると考 えられる老人の精神疾患, とくに老化性痴呆に対し, 病 院, 施設の長期滞在者を増やさぬよう, デイケア, 短期 滞在, 訪問看護といった地域ケアを進めていく対策を,
急速に準備する必要に迫られている.

\section{文献}

1）加藤正明 : 老年精神疾患の疫学，加藤，長谷川 編「老年精神医学」25，1973.

2）加藤正明 : 老人の精神医療に関する現状と問題 点, 精神誌 $78: 10 \cdot 11,643-652,1976$.

3) 厚生省公衆衛生局: わが国活ける精神障害の 現状 1965.

5）長谷川和夫, 柄沢昭秀ほか : 老年精神疾患の疫 学的研究, 慈大精神神経科教室編 : 新福尚武教 授退職記念論文集 342-354，1979。 